\title{
Painting the Full Picture:
}

\section{The Conversions of Economic, Cultural, Social and Symbolic Capital}

\author{
Tobias Pret, Eleanor Shaw and Sarah Drakopoulou Dodd \\ Hunter Centre for Entrepreneurship, University of Strathclyde, UK
}

\begin{abstract}
The interplay between different forms of capital is not well understood; this article, therefore, explores how and why entrepreneurs convert their available economic, cultural, social and symbolic capital. We utilise Bourdieu's theory of practice as a conceptual framework to explore the lived experiences of 10 craft entrepreneurs. This study reveals that transforming capital is a natural and enjoyable process, with our findings highlighting the convertible, multifaceted nature of different forms of capital. We also uncover previously unidentified forms of capital conversions and demonstrate that the conversion process can involve multiple forms of capital. Furthermore, our findings show that craft entrepreneurs give no primacy to economic capital, whose transformations form part of a larger process of capital conversion.
\end{abstract}

\section{Keywords}

entrepreneurial capitals, Bourdieu, creative industries, practice theory, phenomenological inquiry

\section{Introduction}

Non-financial resources, including social and human capital, play a crucial role in facilitating entrepreneurial processes (Davidsson and Honig, 2003; Jayawarna et al., 2014; Marvel et al., 2014). Accordingly, entrepreneurship scholars have shown a growing interest in investigating the attributes of different types of capital possessed by entrepreneurs (Bhagavatula et al., 2010; Leitch et al., 2013; Stam et al., 2014). However, extant studies have overemphasised the importance of individual capitals, overlooking the versatile nature of alternative forms of capital (Al Ariss and Syed, 2011; Shaw et al., 2008). This study seeks to address this research gap by exploring how and why entrepreneurs convert the different types of resources available to them. While the convertibility of capital has received conceptual consideration (Adler and Kwon, 2002; Coleman, 1988; Nahapiet and Ghoshal, 1998), empirical studies are largely absent from the literature (Scott, 2012).

Addressing calls for greater methodological diversity within entrepreneurship research (Karataş-Özkan et al., 2014; Shepherd, 2015), we chose to conduct a phenomenological inquiry, as proposed by Cope (2005). Thus far, only a small number of entrepreneurship studies have adopted phenomenological approaches (cf. Fiet et al., 2013; Korsgaard and Anderson, 2011; McKeever et al., 2015), despite their capabilities in bridging the gap between the lived experiences of entrepreneurs and extant theoretical models (Cope, 2011). Set within the context of the UK creative industries, our study investigates 10 craft entrepreneurs. Creative industries are particularly compelling sites for scholars interested in the deployment of a range of capitals as they hold an aesthetic logic in tension with a commercial logic, suggesting that interesting and competing capital dynamics may be in place (Glynn and Lounsbury, 2005; McLeod et al., 2009; Townley et al., 2009).

Based on our analysis of the experiences of participants, we identify Bourdieu's (1977, 1984, 1986) theory of practice as an appropriate conceptual lens through which the behaviours of entrepreneurs can be interpreted. Within the entrepreneurship literature, Bourdieu's framework has emerged as a theoretically robust means of exploring the perspectives of entrepreneurs (De Clercq and Voronov, 2009; Patel and Conklin, 2009; Terjesen and Elam, 2009). Our study draws particularly on Bourdieu's (1986) capital theory to distinguish between the economic, cultural, social and symbolic capital possessed by and available to entrepreneurs.

This article makes several theoretical and empirical contributions. We demonstrate how and why craft entrepreneurs convert different forms of capital into economic and non-economic value. In so doing, we reveal hitherto overlooked forms of capital conversions and demonstrate that they can involve multiple forms of 
capital. Almost no inhibitors of capital conversions are uncovered, suggesting that transforming capital is a natural and common process for craft entrepreneurs. Furthermore, our findings clearly show that craft entrepreneurs give no primacy to economic capital. Consequently, we argue that focusing too much on economic capital obscures the importance of cultural, social and symbolic forms of capital and their conversions.

This article is structured as follows. In the next section, we explore the entrepreneurship literature on capital forms and conversions and briefly review Bourdieu's $(1977,1984,1986)$ theory of practice. We then justify our choice of the creative industries as a research context, before explaining our methodology. Subsequently, we present our empirically grounded findings and compare capital conversions conducted by our participants with those suggested by entrepreneurship research. Finally, we draw conclusions and consider implications for theory and practice.

\section{Literature review}

\section{Deficiencies in the extant literature}

Investigating the manner in which entrepreneurs utilise and manage resources continues to capture academic interest (Baker and Nelson, 2005; Greene and Brown, 1997; Sullivan and Ford, 2014). However, the extant body of research on different types of capital is disjointed, leading to some divergent and even conflicting findings. For example, several scholars have explored the use of symbolic resources (Fuller and Tian, 2006; Lounsbury and Glynn, 2001; Zott and Huy, 2007), drawing on the related concepts of legitimacy, status and reputation (Bitektine, 2011; Packalen, 2007). Surprisingly, many studies that focus either on reputation (Boyd et al., 2010; Reuber and Fischer, 2007; Rindova et al., 2005) or legitimacy (Garud et al., 2014; Überbacher, 2014; Wry et al., 2011) make little or no reference to each other's literatures and thus, miss an opportunity to connect these ideas to wider academic debates.

Additionally, due to the multitude of definitions, the meanings of some concepts, such as human or social capital, remain ambiguous (Anderson et al., 2007; Marvel et al., 2014; Ployhart et al., 2014). Consequently, findings regarding the role of such capitals in entrepreneurship are inconsistent and comparisons of research results complicated (Adler and Kwon, 2002; Gedajlovic et al., 2013; Jayawarna et al., 2014). Furthermore, most studies that investigate entrepreneurial resources only focus on individual forms of capital (Bowey and Easton, 2007; Casson and Della Giusta, 2007; Stam et al., 2014). The emerging body of research that incorporates two forms of capital (Bhagavatula et al., 2010; Davidsson and Honig, 2003; Grichnik et al., 2014) or three forms (Brüderl and Preisendörfer, 1998; De Clercq et al., 2013; Ram et al., 2008) has not explicitly examined their convertibility.

Our article seeks to address this research gap by investigating how and why entrepreneurs in the creative industries convert the different types of resources available to them. Cognisant of the deficiencies in the extant literature, this study employs Bourdieu's $(1977,1984,1986)$ theory of practice as a conceptual framework to explore the practices of participants, as it accounts for a variety of resources entrepreneurs may utilise and clearly defines such capitals. ${ }^{1}$

\section{Bourdieu's theory of practice}

Bourdieu's theory of practice comprises the three interrelated concepts of capital (Bourdieu, 1986), field (Bourdieu, 1984) and habitus (Bourdieu, 1977). Essentially, Bourdieu proposes that individual actors compete for economic, cultural, social and symbolic capital in order to gain dominant positions within institutional fields and that their actions are patterned by a socially-shaped habitus (Karataş-Özkan, 2011; Özbilgin and Tatli, 2005). Capital acts as the exchange mechanism by which power-relations are legitimated and sustained (De Clercq and Voronov, 2009; Stringfellow et al., 2014). Every institutional field develops and enacts its own specific forms, volumes and distribution of capital (Drakopoulou Dodd et al., 2014; Lawrence, 2004). The struggle for capital is mainly a subconscious process, directed by habitus (Tatli et al., 2014). Habitus represents the 'rules of engagement (modus operandi)' (Anderson et al., 2010: 124) and provides us with a sense of how to react to different situations (Karataş-Özkan and Chell, 2015; Light and Dana, 2013). Finally, Bourdieu (1984) 
proposes that individual interest in competing for status is based on a shared illusio. Illusio is field-specific and causes actors to accept the significance of acquiring capital (Friedland, 2009; Golsorkhi et al., 2009).

\section{Forms of capital and their conversions}

In this section we discuss forms of capital, as defined by Bourdieu (1986) and illustrated in Figure 1, in relation to entrepreneurship literature on capitals and their conversions.

\section{-- INSERT FIGURE 1 ABOUT HERE --}

Bourdieu (1986) proposes that economic capital materialises as financial assets and other tangible and intangible business assets. Entrepreneurs can generate income by converting other types of capital into economic capital (Chandler and Hanks, 1998; Jonsson and Lindbergh, 2013). Conversely, transforming economic capital into cultural, social and symbolic capital is more complex and time-consuming (Greve and Salaff, 2003; Jayawarna et al., 2014). For example, entrepreneurs can perform such conversions by investing in an elite education to develop their skills, networks and reputation (Randle et al., 2014; Shaw et al., 2013). It has been argued that economic capital is the most critical asset for small firms (Brinckmann et al., 2011; Winborg and Landström, 2001). However, Bourdieu (1984) warns against assuming the primacy of economic capital, arguing that commitment to the rules of the economic 'game' is a culturally grounded social construction. Accordingly, we attempt to broaden our appreciation of the importance of other forms of capital to the entrepreneur.

Bourdieu (1986) conceptualises three forms of cultural capital: long-lasting personal dispositions (embodied form), cultural goods (objectified form) and educational qualifications (institutionalised form). Thus, cultural capital is an extension of the concept of human capital, which refers mainly to the skills, training and work experience of entrepreneurs (Elam, 2008). Within entrepreneurship research, cultural capital has attracted scholarly interest (De Clercq and Voronov, 2009; Jayawarna et al., 2014; Kim et al., 2006). Concerning its convertibility, Anderson and Miller (2003) propose that high socio-economic status (embodied cultural capital) allows entrepreneurs to develop wider social networks. Additionally, skills enable the creation of cultural artefacts that possess economic value (Bhagavatula et al., 2010; Townley et al., 2009) and industry experience can facilitate reputation building (Beverland, 2005; Bitektine, 2011). At the same time, a lack of cultural capital can limit the ability to 'fit in' with accepted norms (habitus), which can restrict access to social networks and impede status enhancement (De Clercq and Voronov, 2009; Lounsbury and Glynn, 2001).

Bourdieu (1986) defines social capital as the sum of all actual and potential resources that can be accessed through a durable network of relationships. ${ }^{2}$ Membership within a network enables entrepreneurs to benefit from collectively owned and shared capital (Bowey and Easton, 2007; Miller et al., 2007; Rooks et al., 2014). However, the willingness to share resources depends on the strength of the ties connecting network members (Granovetter, 1973; Jack, 2005). Furthermore, creating and maintaining relationships can be a demanding process (Nahapiet and Ghoshal, 1998; Vershinina et al., 2011). As discussed by Anheier et al. (1995), it is easier to transform cultural capital into social capital than vice versa. Nevertheless, social capital can be converted into cultural capital through the processes of relational learning (Karataş-Özkan, 2011). Regarding the conversion of social capital into symbolic capital, it has been argued that affiliation with reputable others can create a spill-over effect (Reuber and Fischer, 2005), while association with unreliable partners can impede reputation building (Lange et al., 2011).

Once any of the aforementioned types of capital are recognised, they can generate symbolic capital (Bourdieu, 1986). This form of capital is particularly powerful as it can engender belief in the quality of products, generate trust and legitimise the actions of entrepreneurs (De Clercq and Voronov, 2009; Harvey et al., 2011). Symbolic capital is usually associated with the possession of prestige, status and a positive reputation (Terjesen and Elam, 2009). It is objectified in awards and recognitions, but its actual value to the entrepreneur depends on the importance others attribute to such capital (Fuller and Tian, 2006). Symbolic capital, such as prestige, can be converted into social and cultural capital by facilitating access to social networks and exclusive education (Lawrence, 2004; McLeod et al., 2009). Accordingly, the lack of such symbolic resources can impede entrepreneurial processes and have a negative long-term effect on firm reputation and performance (Fischer and Reuber, 2007; Reuber and Fischer, 2007). 


\section{The contribution of this study}

The preceding literature review indicates the variety of entrepreneurship studies that investigate different forms of capital. However, the extant body of research is disjointed and the majority of studies examine only one or two forms of capital. Consequently, most fail to consider the bigger picture of how and why entrepreneurs transform and combine the various types of resources at their disposal. In answer to the call for further research on the interplay of different forms of capital (De Clercq et al., 2013; Shaw et al., 2008), our study investigates the conversions of economic, cultural, social and symbolic capital. Although scholars have considered the convertibility of capital (Adler and Kwon, 2002; Coleman, 1988; Nahapiet and Ghoshal, 1998), they have not empirically verified their conceptual ideas regarding this entrepreneurial practice. Table 1 summarises the findings of our literature review, compiling previously discussed facilitators and inhibitors of capital conversion. By comparing these concepts with the findings of our in-depth study of entrepreneurs in the creative industries, this paper addresses a contemporary gap in the literature. As will be shown, extant research has overemphasised the importance of individual capitals and overlooked the convertible, multifaceted nature of different forms of capital.

\section{-- INSERT TABLE 1 ABOUT HERE --}

\section{Context and Methods}

\section{Creative industries context}

There are several reasons why creative industries are particularly compelling sites of study for those interested in the deployment of a range of capitals. It has been argued that creative professionals must find a balance between aesthetic logic and economic logic (Glynn and Lounsbury, 2005; McLeod et al., 2009; Townley et al., 2009), which suggests that interesting and competing capital dynamics may be in place. ${ }^{3}$ Furthermore, the significance of the creative industries to national economies is expanding dramatically and the sector merits investigation as a core post-industrial institution (Coulson, 2012; UNDP, 2013). Within the UK, creative industries are growing faster than most other economic sectors and account for 5.6 per cent of total employment (DCMS, 2014). Within the creative field, we decided to investigate craft entrepreneurs for three main reasons. First, craft entrepreneurs have rarely been examined by entrepreneurship research, although they have been shown to find creative ways to mobilise resources and exploit opportunities (Bhagavatula et al., 2010; Fillis, 2004; Kuhn and Galloway, 2015). This omission leaves a gap in our understanding of a sector that is steadily growing, consisting of over 23,000 businesses in the UK and producing a turnover of around $£ 1.9$ billion (Bennett et al., 2014; Burns et al., 2012). Second, Bourdieu (1986: 242) argues that human behaviour cannot be fully understood if research focuses solely on examining economic motives; it also needs to account for 'activities of art-for-art's sake'. Investigating craft entrepreneurs, who are driven by both commercial and lifestyle-oriented goals (Eikhof and Haunschild, 2007; Tregear, 2005), presents an apposite avenue of inquiry for this study. Third, the first author has previously been employed as a craft professional, which facilitated building rapport with participants and encouraged entrepreneurs to share their experiences more openly. Gaining such deep insights is of major importance for phenomenological research (Sandberg, 2000).

\section{Philosophical considerations}

In answer to the call for more methodological and paradigmatic diversity in the study of entrepreneurship (Grant and Perren, 2002; Karataş-Özkan et al., 2014; Shepherd, 2015), we chose to embrace an interpretivist perspective and conduct a phenomenological inquiry (Cope, 2005). To date, only a small number of entrepreneurship studies have adopted phenomenological approaches (cf. Lewis, 2015; Spivack et al., 2014; Zou et al., 2015), despite their capabilities in 'developing both new theoretical constructs and enhancing the potency of existing ones, bridging the gap between real-life occurrences and theoretical concepts' (Cope, 2011: 610). As described by Berglund (2007), phenomenological research explores the meanings that participants attribute to their lived experiences in order to gain a deep understanding of their personal and social worlds. This perspective is firmly set within the interpretivist paradigm (Burrell and Morgan, 1979), as it rejects the 
ontological separation of reality and consciousness and seeks to comprehend the subjective views of participants (Sanders, 1982).

Cope (2005) presents a comprehensive review of philosophical and methodological considerations related to phenomenological inquiries. Significantly, this research approach draws on Husserl's transcendental phenomenology, which requires researchers to bracket their preconceptions in order to understand phenomena free from presuppositions (Hycner, 1985). ${ }^{4}$ However, it is important to acknowledge that our interest in discussing capital conversions may have inadvertently influenced our framing of questions to a small degree. As our research does not conform to the prevailing functionalist paradigm (Grant and Perren, 2002), its value cannot be judged according to traditional positivist criteria such as reliability, objectivity and generalisability (Sandberg, 2000). Instead, we are explicit about the reasoning behind our research in order to demonstrate its ‘credibility, transferability, dependability and confirmability’ (Lincoln and Guba, 1985: 189).

\section{Sample selection}

We built on the typology of Fillis (2004) to distinguish between different types of craft makers, which enabled us to select participants who can be classified as craft entrepreneurs. Participants in this study had to describe themselves as profit-oriented, opportunity-driven and open to export. ${ }^{5}$ Additionally, they had to operate their own businesses in a dedicated studio or workshop and practise craft as their primary profession. Using prior contacts in craft business networks, we advertised our research to potential participants. We first conducted conversations with interested makers to determine whether they fit our definition of craft entrepreneurs and to start building a rapport. Following the advice of Smith (2004), we chose to include 10 cases in our research, selected through purposeful sampling to comprise a breadth of experiences (Patton, 2002). ${ }^{6}$ It should be noted that although participants are growing their businesses with the intention of creating employment, they are all sole proprietors; thus, our unit of analysis is the business owner - the craft entrepreneur.

\section{Data collection}

The broad aim was to investigate how and why craft entrepreneurs convert the different types of resources accessible to them. Interviews began with the open-ended questions: 'Tell me about your background' and 'Tell me about your business'. In order to make participants feel comfortable (Cope, 2005), interviews were conducted in their workshops or studios, outside of normal opening hours. Using everyday language (Patton, 2002), initial expositions were followed up with questions that allowed participants to expand upon their stories, often referring to critical incidents, which enabled us to gain a deeper understanding of their lived experiences (Thompson et al., 1989). Interviews lasted between two and three hours and provided us with large amounts of information-rich empirical data (approximately 400 single-spaced transcript pages in total). We were surprised by the level of openness and emotion displayed by participants, who seemed to welcome the opportunity to discuss their experiences and share privileged information, knowing that their personal details would be kept confidential. However, having the interviews directed by what the entrepreneurs wanted to share also presented difficulties. As some control over interviews had to be given up, participants occasionally recounted topics unrelated to their business activities. In addition to interviews, entrepreneurs were observed at events, such as craft shows and exhibitions. When possible, conversations took place to gain a greater appreciation of the behaviours of participants (McKeever et al., 2015). Furthermore, we accessed available documents, such as business websites and blogs, to broaden our understanding of the practices of entrepreneurs (Patton, 2002) and to increase the confirmability of our study (Lincoln and Guba, 1985).

\section{Data analysis}

Interviews were recorded and transcribed verbatim to enable systematic analysis of our raw data. We followed the principles of interpretative phenomenological analysis (Cope, 2011; Smith et al., 2009). First, we familiarised ourselves with the cases before immersing ourselves in their contexts by highlighting potentially significant passages in the transcripts, enabling us to discover and code emerging intra-case themes (Hycner, 1985). We completed this procedure prior to comparing themes between cases and searching for patterns to develop superordinate categories (Smith et al., 2009). It should be noted that while we managed to gain deep 
insights into the lived experiences of the entrepreneurs, immersing ourselves into the messy realities of their lives proved to be a challenging process (Cope, 2005). We proceeded by developing interpretive case summaries, which we shared with our participants to check their accuracy and which we then used to inform our analysis of data. Afterwards, in the final stage of analysis, we ceased bracketing our prior knowledge of related academic theory (Hycner, 1985) and 'recontextualized' our findings by 'putting the new knowledge about the phenomena and relations back into the context of how others have articulated the evolving knowledge' (Marlow and McAdam, 2013: 10). This abstraction process involved moving iteratively between existing theory and our data to gain a higher level of conceptualisation (Cope, 2011). Like Terjesen and Elam (2009: 1100), during this process we realised that our 'individual-level data seemed to offer a view of entrepreneurship consistent with Bourdieu's theory', which is why we decided to apply Bourdieu's conceptual framework to our data. We therefore re-coded our data, this time utilising the computer-based data processing tool NVIVO. The Appendix illustrates how we moved from our raw data to the refined themes and shows how we operationalised the different types of capital. The outcomes of our analysis are presented in the following sections and structured to highlight the distinctive conversions found between each form of capital.

\section{Findings and Discussion}

\section{Conversions of economic capital}

One of the most significant findings to emerge is that craft entrepreneurs seem to give no primacy to economic capital when converting their varied capitals. Instead, we find that economic capital conversions are part of a larger process of capital conversion for entrepreneurs. Table 2 presents examples of the references participants made to spending their financial resources on developing other types of capital. These include increasing social capital by paying membership fees to join guilds and boosting symbolic capital by purchasing advertisements in prestigious magazines. Only Fred referred to the tuition costs incurred when developing his cultural capital through formal education and only because he was not satisfied with the quality of training. This indicates the lesser importance participants placed on such expenses when contrasted to highly valued cultural capital (Scott, 2012).

\section{-- INSERT TABLE 2 ABOUT HERE --}

We discover no evidence of economic capital having been converted into social or cultural capital through such means as attending expensive elite educational establishments (Jayawarna et al., 2014; Randle et al., 2014). Neither do participants seek to garner symbolic capital by engaging in charitable giving (Shaw et al., 2013; Stringfellow et al., 2014). Helping others does matter to craft entrepreneurs but they do so by providing cultural capital (see below) instead of economic capital and primarily for altruistic reasons, such as perpetuating the industry. Although not explicitly aimed at growing their businesses, such efforts help entrepreneurs stay true to their self-identity and the image they portray to audiences over time (Svejenova, 2005). ${ }^{7}$ As shown in Table 3 , participants do not refer to the inhibitors identified in the literature, such as the required time and effort associated with conversions from economic capital (Greve and Salaff, 2003; Jayawarna et al., 2014). The only sustained mentions of conversions into economic capital relate to making sales, which is, after all, a core business function. For the craft entrepreneurs in this study, cultural, social and symbolic capital play a role equally important to economic capital.

\section{-- INSERT TABLE 3 ABOUT HERE --}

Recognising this, we argue that economic capital has perhaps become something of an obsession within the entrepreneurship literature, in spite of sustained and clear evidence of the significance of other types of capital (cf. Davidsson and Honig, 2003; Jayawarna et al., 2014; Zott and Huy, 2007). Bourdieu (1984) himself warned that such a conceptual attachment to the primacy of economic capital indicates that one conforms to the illusio of market rhetoric - that one has bought into a belief in the financial stakes of the entrepreneurship game. It is time to recognise that economic capital may not play a dominant role in all forms of entrepreneurship (Amit et al., 2001; Jennings and Brush, 2013; Rindova et al., 2009), especially in the creative industries (Drakopoulou Dodd, 2014; Eikhof and Haunschild, 2007; Scott, 2012). While sales are clearly an important source of income 
for craft entrepreneurs, conversions to and from economic capital represent only a portion of capital conversions. Consequently, focusing too much on economic capital obscures the importance of other forms of capital and their conversions. We argue that, whilst studying capital flows and exchanges within a given field, it is crucial to acknowledge the generative grammar of the field (habitus), as well as the stakes for which field members strive (illusio) (Friedland, 2009; Golsorkhi et al., 2009). Concentrating only on economic capital is to import a neo-classical, market-driven perspective into a field that may have quite different patterns of practice and priorities.

\section{Conversions of cultural capital}

The importance of cultural capital to entrepreneurs in creative industries is revealed in our study and also existing research (McLeod et al., 2009; Townley et al., 2009). Skills and practical experiences are the foundations upon which the enterprise is built and the main vehicle through which economic capital is generated. As Grace explains, being 'taught to sew ... I think that's the grounding really'. The only distinct difference in opinion among participants relates to the importance of educational qualifications, which those entrepreneurs who craft lower-priced products consider less essential. Becky, for example, declares that 'a professional qualification is not really necessary'. We find that these entrepreneurs prefer knowledge acquisition through experimentation and self-directed learning (Marvel et al., 2014), because they value practical experience above all else. Additionally, craft entrepreneurs draw on the cultural capital of their network ties to address gaps in their own skills and knowledge (Bhagavatula et al., 2010; Sullivan and Ford, 2014).

\section{-- INSERT TABLE 4 ABOUT HERE --}

Table 4 provides examples of the variety of ways in which participants describe converting their cultural capital. In addition to selling the items they produce, craft entrepreneurs turn their cultural capital into economic capital by teaching their skills to others. However, we discover that transforming cultural capital into social capital within their own communities is equally important and part of to the 'rules of the game' (habitus). Surprisingly, we find that craft entrepreneurs share their cultural capital freely within their networks, thereby building and reinforcing social capital ties (Kuhn and Galloway, 2015; Miller et al., 2007; Rooks et al., 2014). Elaine believes the reason for such behaviour is that 'you want to help one another out, because you would hope somebody [else] would do it for you and ... our styles are all really quite different'. Fred explains that he is willing to pass on skills, because 'there is courses closing all over the place, it's becoming increasingly difficult to actually do ceramics full-time'. Thus, our findings corroborate the assumption that the behaviours of entrepreneurs are driven by more than self-interest (Jayawarna et al., 2013; Jennings and Brush, 2013; Rindova et al., 2009). Regarding the conversion of cultural capital to symbolic capital, we find that participants build reputations through the development of individual styles. Craft entrepreneurs engage in this practice to reduce the risk of plagiarism and differentiate themselves competitively (Tan et al., 2013).

As the quality of craft pieces depends upon the skills of the maker, cultural capital plays an especially important role in shaping the successes of craft entrepreneurs. Furthermore, cultural capital appears to have high conversion rates into both symbolic and economic capital, as gifted craft entrepreneurs are awarded high levels of prestige and valuable commissions. As Table 5 indicates, we find no evidence of the inhibitors that have been associated with cultural capital conversions in the literature (De Clercq and Voronov, 2009; Lounsbury and Glynn, 2001). Rather, converting cultural capital into economic, social and symbolic capital seems to be a natural and even enjoyable process.

-- INSERT TABLE 5 ABOUT HERE --

\section{Conversions of social capital}

Table 6 illustrates strong evidence for the importance of network ties to resource accumulation and brokering of customer ties (Jack, 2005; Shaw, 2006). As has been found in previous research (Arregle et al., 2015; Greve and Salaff, 2003), strong ties with family and friends form a reservoir of social capital upon which entrepreneurs are able to draw and convert into economic capital. This occurs through the provision of free or discounted 
resources and through help in generating sales (Gras and Nason, 2015). Furthermore, attending networking events, such as craft shows, helps entrepreneurs find 'some really nice collectors, who come back to me time and time again' (Alison), which, in turn, increases their economic capital (Jack et al., 2010). It is important for participants to attend such events, because craft products attract a niche market. As Becky points out, 'unless you are a serious knitter, you're not just gonna come in off the street and buy something'.

\section{-- INSERT TABLE 6 ABOUT HERE --}

Social and cultural capital also come together in generating economic capital when craft entrepreneurs refer client enquiries to other makers who they know to be more specialised for a particular commission. Craig explains that 'sometimes there are enquiries ... and then they [peers] will say, "Oh, well, you know, the best one to contact is Craig"'. Furthermore, Denise describes that, "I have students coming through some of my classes and I would definitely call them [to offer work]', when there are more orders than she can handle. In other words, once Denise has imparted cultural capital to her students, she then accesses these social capital ties and their skills to produce economic capital by charging a commission. This demonstrates that conversions can involve not only two, but multiple forms of capital - a process that, thus far, has been largely overlooked in the entrepreneurship literature.

We also find many rich examples of relational learning enabled by strong ties (Karataş-Özkan, 2011; Leitch et al., 2013). Conversions of social capital into cultural capital are often conducted through acquiring skills from other makers, suppliers, family and friends (Elsbach and Flynn, 2013). As Elaine explains, sharing cultural capital starts at 'art school, where you kind of feed off one another'. In addition to the resultant financial benefits, craft entrepreneurs co-create novel cultural capital because they feel 'it's quite nice to work together' (Fred) and because of prior habituation: 'We [makers] have always been sort of swapping ideas' (Hannah). Furthermore, we find evidence of the use of social capital to leverage access to the cultural capital of contacts where entrepreneurs lack specific skills. Irrelevant or insufficient prior training seem to drive engagement in such conversion processes. Elaine, for example, laments that at college 'you were not taught ... any business studies whatsoever'.

Another key issue that concerns participants is how to compensate for a lack of symbolic capital. Ties with well-placed others, such as publishers or acclaimed peers, help them offset such deficiencies. Craft entrepreneurs also build reputation through their embeddedness in relevant networks (Casson and Della Giusta, 2007; Randle et al., 2014). As Elaine explains, membership in her guild allows her to apply to 'a show that is ... very highly regarded within our trade and you have to be invited to apply'. Again, as Table 7 indicates, participants do not refer to inhibitors of social capital conversions, such as the requisite time and effort discussed in the academic literature (cf. Anheier et al., 1995; Nahapiet and Ghoshal, 1998). This suggests that the benefits of converting social capital are accessible to craft entrepreneurs and offer a strong route for venture launch and growth.

\section{-- INSERT TABLE 7 ABOUT HERE --}

\section{Conversions of symbolic capital}

Symbolic capital is found to be an especially mutable capital form, readily exchangeable into all of the other three forms of capital (see Table 8). Congruous with extant research (cf. Shaw et al., 2008; Zott and Huy, 2007), we find that reputation and signs of prestige lead to enhanced economic capital (through sales). Building and maintaining a positive reputation over time appears to be crucial as it enables customers to 'buy with confidence, because they know I'm not just gonna disappear tomorrow' (Alison). Furthermore, it helps verify the quality of products and convince customers to pay premium prices (Rindova et al., 2005).

\section{-- INSERT TABLE 8 ABOUT HERE --}

When participants received legitimating acclaim by winning competitions, prizes and awards, they also found new opportunities to engage in relational learning through exposure to experts in their field. Such conversions of symbolic capital into cultural capital have previously been observed within professional fields 
(Lawrence, 2004), but not within an entrepreneurial context. This finding fits well with recent theories of relational learning (Karataş-Özkan, 2011; Leitch et al., 2013): by enhancing status within a given field, the acquisition of symbolic capital allows entrepreneurs to exploit higher-level learning contexts. Craft entrepreneurs engage in these capital conversions as expert advice can help develop style essential to long-term success (Bhagavatula et al., 2010). Such exchanges are not only one-way, but also benefit the experts as they gain ideas and a fresh perspective from protégés (McLeod et al., 2011).

Similar to other creative industries (Coulson, 2012; McLeod et al., 2009), craft entrepreneurs also use their symbolic capital to expand networks and increase social capital. Positive online feedback facilitates this process, as 'new ones [customers] especially, ... the only thing they see is ... comments on social media' (Craig). Thus, 'being able to say, "I'm an award winner"' (Alison), helps participants grow networks. Some customers even come to expect that acclaimed craft entrepreneurs continue engaging in activities that maintain their reputation. As Elaine describes, because 'I have that reputation of being an international maker ... they [collectors] want to hear that you're not just sitting in here'. Symbolic capital is, therefore, not only used to increase other types of capital, it can also turn into a prerequisite for sustaining high levels of social capital (Deephouse and Carter, 2005).

Overall, symbolic capital appears to have particularly high conversion rates into economic and social capital, as reputable craft entrepreneurs can charge high prices for products and gain loyal collectors. Regarding the inhibitors of conversion processes, participants acknowledge the potentially harmful impact of negative or neutral online feedback (Fischer and Reuber, 2007). However, as Table 9 shows, this is the only inhibitor of capital conversions discussed by our participants. This suggests that craft entrepreneurs have a positive attitude towards transforming capital from one form into another.

-- INSERT TABLE 9 ABOUT HERE --

\section{Conclusions and Implications}

Our phenomenological approach enabled us to contribute to developing theory that supports analysis of forms of capital, particularly of how they merge and meld to support venture sustainability and growth. Our findings demonstrate a variety of capital conversions in which craft entrepreneurs regularly engage. We enrich existing scholarship by providing empirical evidence of conversions that have previously only received conceptual attention (Adler and Kwon, 2002; De Clercq and Voronov, 2009; Nahapiet and Ghoshal, 1998). Furthermore, we extend prior research by highlighting hitherto unidentified forms of capital conversions. Examples of such newly identified conversions include the deployment of symbolic capital to generate high-level cultural capital and the cooperative process of converting social capital into cultural capital by co-creating novel cultural artefacts. We also reveal that capital conversions can involve multiple forms of capital. As such, our findings highlight the complex nature of capital conversations. We argue that this complexity warrants further examination and propose that future research investigate how several forms of capital can be combined to increase the amount of capital possessed by entrepreneurs. Thus far, the processes involved have been largely overlooked within the entrepreneurship literature.

We also demonstrate that the value of different types of capital and their conversion rates into others resources can vary. Overall, we find that cultural and symbolic capital have particularly high conversion rates for craft entrepreneurs. However, we expect that this valuation pattern may differ considerably in other industries and suggest that future research investigate the conversion rates associated with capital transformations in other contexts. Furthermore, longitudinal research designs could produce a more comprehensive understanding of temporal changes.

This article brings together a diverse range of largely disjointed literature on individual forms of capital and their conversions. In addition, our study highlights the value of employing Bourdieu's (1977, 1984, 1986) conceptual framework to define the various forms of capital and to analyse the use and management of resources by entrepreneurs. If more studies were to adopt Bourdieu's perspective, this could help reduce inconsistencies and increase the compatibility of research findings.

To date, cultural capital has received only limited attention within entrepreneurship research (De Clercq and Voronov, 2009; Jayawarna et al., 2014; Kim et al., 2006). Nevertheless, we find that cultural capital is a strong driver of sales and a facilitator for building networks and legitimacy for craft entrepreneurs. This 
corresponds with the findings of studies into other creative and cultural industries (McLeod et al., 2009; Townley et al., 2009). Consequently, we would encourage further research into the effects of cultural capital on the practices of entrepreneurs.

Additionally, our study uncovers almost no evidence of the inhibitors of capital conversions proposed in the extant literature (Bhagavatula et al., 2010; Lange et al., 2011; Shaw et al., 2013) ${ }^{8}$ This does not mean that such inhibitors do not exist, but that they were not significant for our participants. When invited to freely articulate their stories (Cope, 2005) - rather than having their narratives shaped by an interview protocol participants recounted numerous rich capital conversions without referring to barriers to such processes. At the very least, this suggests an ease, a naturalness, a speed and flexibility to capital conversion which has not received adequate attention to date (Scott, 2012).

By adopting a phenomenological approach, this study has liberated participants to express their lived experiences in a form that is free from the assumptions of the researchers (Hycner, 1985). In so doing, it shows that craft entrepreneurs seem to give no primacy to economic capital when converting the various types of resources they possess. Instead, we find that economic capital conversions are part of a larger process of capital conversion. Clearly, gaining economic capital through sales is essential (Winborg and Landström, 2001). However, the day-to-day activities of craft entrepreneurs involve exchanging a wide range of resources. It is the proficiency in performing these other conversions that affects the abilities of craft entrepreneurs to accumulate economic capital.

We found that craft entrepreneurs were willing to share their non-financial capital with peers in order to support one another and advance the industry as whole (Coulson, 2012; Kuhn and Galloway, 2015). This contradicts prevailing beliefs (Barney, 1991; Brinckmann et al., 2011), which suggest that entrepreneurs are primarily driven by competition- and profit-oriented behaviours. Instead, our study shows that entrepreneurs value the benefits derived from relational learning and exchanging ideas more than they fear potential losses of intellectual property, customers or sales. As such, their behaviour suggests a much more positive outlook on capital exchanges in the market place, including those with apparent 'competitors'.

This research also carries several practical implications for entrepreneurs. Based on the experiences of participants, we discuss a range of ways in which entrepreneurs can utilise and leverage economic, cultural, social and symbolic capital to manage and develop the business. Therefore, we demonstrate that nascent entrepreneurs should not be deterred from starting a venture solely because they lack an individual resource (such as money). Instead, they should be aware of the variety of alternative resources that can be employed to compensate for deficient forms of capital. As we have shown, this can entail asking friends, family, suppliers and even potential competitors for help with developing the business. Those who work in the same industry will not necessarily compete for the same (niche) market and, as such, approaching potential 'competitors' may be less risky than feared. Furthermore, we demonstrate that entrepreneurs who require specialised skills and education can benefit from transforming social and symbolic capital to increase their levels of cultural capital. Attending shows and exhibitions is a particularly useful way for craft entrepreneurs to learn from experienced others. Our study also emphasises the importance of symbolic capital for entrepreneurs in the creative industries. Entering competitions can help craft entrepreneurs develop this particularly mutable form of capital. Even if a piece of work is not shortlisted for an award, exposure to the public can help craft entrepreneurs find customers who are interested in their styles. Finally, our research highlights the value of engaging in a dialogue with practicing entrepreneurs in order to learn directly from their experiences.

\section{Funding}

This research received no specific grant from any funding agency in the public, commercial, or not-for-profit sectors.

\section{Notes}

1. It should be noted that we decided to utilise Bourdieu's framework only after we had completed our data collection, in line with our philosophical stance discussed in the methods section. When we conducted this research, it was important that our prior knowledge of various forms of capital did not influence our perceptions of participant perspectives. 
2. Although Nahapiet and Ghoshal's (1998) multidimensional view of social capital is more commonly applied within entrepreneurship research (Gedajlovic et al., 2013), it is difficult to distinguish their concept of social capital from human capital (Lester et al., 2008). As this study investigates conversions of distinct forms of capital, it would not be practical for us to employ this concept.

3. It may appear counter-intuitive to select a context in which entrepreneurs are likely to seek and value esoteric forms of capital. However, as we sought to gain a comprehensive understanding of the various possible capital conversions entrepreneurs may conduct, it appeared sensible to investigate creative industries. Due to the phenomenological nature of this research, our findings and implications are, of course, explicitly about craft entrepreneurs, but the conclusions we draw will hopefully spark future research in other contexts.

4. Sanders (1982: 355) defines bracketing as 'the temporary suspension of all existing personal biases, beliefs, preconceptions, or assumptions in order to get straight to the pure and unencumbered vision of what a thing "essentially is." As Cope (2005) points out, detaching oneself from one's beliefs about the subject under investigation facilitates going beyond the 'natural standpoint' of the attached observer. In practice, we sought to put our judgments and prior knowledge about the practices of creative entrepreneurs aside to open ourselves to understanding the perspectives of participants.

5. Fillis (2004) differentiates between four types of craft makers: life styler, idealist, late developer and entrepreneur. Cognisant of the differences, we did not invite makers to participate if they described themselves in ways which suggested they were risk-adverse, primarily interested in producing art for art's sake or indifferent to business growth.

6. Full details of the sample can be provided by the authors on request.

7. While the traditional philanthropic conversion of economic to symbolic capital (by giving money to increase one's reputation) was not found in this study, it should be noted that some behaviours and goals of participants are similar to those of philanthropists (Harvey et al., 2011; Shaw et al., 2013).

8. It should be noted that the absence of inhibitors in our study might be an effect of our case selection and the context our study investigates. Furthermore, it is possible that participants chose to focus mainly on the positive aspects of their stories when recounting their experiences in the phenomenological interviews. More structured research and investigations in other contexts are therefore needed to confirm this finding.

\section{References}

Adler PS and Kwon S-W (2002) Social Capital: Prospects for a new Concept. Academy of Management Review 27 (1): 17-40.

Al Ariss A and Syed J (2011) Capital Mobilization of Skilled Migrants: A Relational Perspective. British Journal of Management 22 (2): 286-304.

Amit R, MacCrimmon KR, Zietsma C and Oesch JM (2001) Does money matter?: Wealth attainment as the motive for initiating growth-oriented technology ventures. Journal of Business Venturing 16 (2): 119 143.

Anderson AR, Drakopoulou Dodd S and Jack SL (2010) Network practices and entrepreneurial growth. Scandinavian Journal of Management 26 (2): 121-133.

Anderson AR and Miller CJ (2003) "Class matters": human and social capital in the entrepreneurial process. The Journal of Socio-Economics 32 (1): 17-36.

Anderson AR, Park J and Jack SL (2007) Entrepreneurial Social Capital: Conceptualizing Social Capital in New High-tech Firms. International Small Business Journal 25 (3): 245-272.

Anheier HK, Gerhards J and Romo FP (1995) Forms of Capital and Social Structure in Cultural Fields: Examining Bourdieu's Social Topography. American Journal of Sociology 100 (4): 859-903.

Arregle J-L, Batjargal B, Hitt MA, Webb JW, Miller T and Tsui AS (2015) Family Ties in Entrepreneurs' Social Networks and New Venture Growth. Entrepreneurship Theory and Practice 39 (2): 313-344. 
Baker T and Nelson RE (2005) Creating Something from Nothing: Resource Construction through Entrepreneurial Bricolage. Administrative Science Quarterly 50 (3): 329-366.

Barney J (1991) Firm Resources and Sustained Competitive Advantage. Journal of Management 17 (1): 99-120. Bennett J, License A and Tuck F (2014) Measuring the Craft Economy (report). Newcastle: Crafts Council. Berglund H (2007) Researching Entrepreneurship as lived experience. In: Neergaard H and Ulhøi JP (eds) Handbook of qualitative research in entrepreneurship. Cheltenham: Edward Elgar, pp. 75-93.

Beverland MB (2005) Crafting Brand Authenticity: The Case of Luxury Wines. Journal of Management Studies 42 (5): 1003-1029.

Bhagavatula S, Elfring T, van Tilburg A and van de Bunt GG (2010) How social and human capital influence opportunity recognition and resource mobilization in India's handloom industry. Journal of Business Venturing 25 (3): 245-260.

Bitektine A (2011) Toward a Theory of Social Judgments of Organizations: The Case of Legitimacy, Reputation, and Status. Academy of Management Review 36 (1): 151-179.

Bourdieu P (1977) Outline of a Theory of Practice. Cambridge, MA: Cambridge University Press.

Bourdieu P (1984) Distinction: a social critique of the judgement of taste. Cambridge, MA: Harvard University Press.

Bourdieu P (1986) The Forms of Capital. In: Richardson JG (ed.) The handbook of theory and research for the sociology of education. New York, NY: Greenwood Press, pp. 241-258.

Bowey JL and Easton G (2007) Entrepreneurial Social Capital Unplugged: An Activity-based Analysis. International Small Business Journal 25 (3): 273-306.

Boyd BK, Bergh DD and Ketchen DJ (2010) Reconsidering the Reputation-Performance Relationship: A Resource-Based View. Journal of Management 36 (3): 588-609.

Brinckmann J, Salomo S and Gemuenden HG (2011) Financial Management Competence of Founding Teams and Growth of New Technology-Based Firms. Entrepreneurship Theory and Practice 35 (2): 217-243.

Brüderl J and Preisendörfer P (1998) Network support and the success of newly founded businesses. Small Business Economics 10 (3): 213-225.

Burns J, Gibbon C, Rosemberg C and Yair K (2012) Craft in an Age of Change (report). London: Crafts Council, Creative Scotland, Arts Council of Wales and Craft Northern Ireland.

Burrell G and Morgan G (1979) Sociological Paradigms and Organizational Analysis. London: Heinemann Educational Books.

Casson M and Della Giusta M (2007) Entrepreneurship and Social Capital: Analysing the Impact of Social Networks on Entrepreneurial Activity from a Rational Action Perspective. International Small Business Journal 25 (3): 220-244.

Chandler GN and Hanks SH (1998) An examination of the substitutability of founders human and financial capital in emerging business ventures. Journal of Business Venturing 13 (5): 353-369.

Coleman JS (1988) Social Capital in the Creation of Human Capital. American Journal of Sociology 94: S95$\mathrm{S} 120$.

Cope J (2005) Researching Entrepreneurship through Phenomenological Inquiry: Philosophical and Methodological Issues. International Small Business Journal 23 (2): 163-189.

Cope J (2011) Entrepreneurial learning from failure: An interpretative phenomenological analysis. Journal of Business Venturing 26 (6): 604-623.

Coulson S (2012) Collaborating in a competitive world: musicians' working lives and understandings of entrepreneurship. Work, Employment \& Society 26 (2): 246-261.

Davidsson P and Honig B (2003) The role of social and human capital among nascent entrepreneurs. Journal of Business Venturing 18 (3): 301-331.

DCMS (2014) Creative Industries Economic Estimates January 2014 (report). London: Department for Culture, Media and Sport.

De Clercq D, Lim DSK and Oh CH (2013) Individual-Level Resources and New Business Activity: The Contingent Role of Institutional Context. Entrepreneurship Theory and Practice 37 (2): 303-330.

De Clercq D and Voronov M (2009) Toward a Practice Perspective of Entrepreneurship: Entrepreneurial Legitimacy as Habitus. International Small Business Journal 27 (4): 395-419. 
Deephouse DL and Carter SM (2005) An Examination of Differences Between Organizational Legitimacy and Organizational Reputation. Journal of Management Studies 42 (2): 329-360.

DiMaggio PJ (1979) On Pierre Bourdieu. American Journal of Sociology 84 (6): 1460-1474.

Drakopoulou Dodd S (2014) Roots radical - place, power and practice in punk entrepreneurship. Entrepreneurship \& Regional Development 26 (1-2): 165-205.

Drakopoulou Dodd S, McDonald S, McElwee G and Smith R (2014) A Bourdieuan Analysis of Qualitative Authorship in Entrepreneurship Scholarship. Journal of Small Business Management 52 (4): 633-654.

Eikhof DR and Haunschild A (2007) For art's sake! Artistic and economic logics in creative production. Journal of Organizational Behavior 28 (5): 523-538.

Elam AB (2008) Gender and entrepreneurship: A multilevel theory and analysis. Cheltenham: Edward Elgar.

Elsbach KD and Flynn FJ (2013) Creative Collaboration and the Self-Concept: A Study of Toy Designers. Journal of Management Studies 50 (4): 515-544.

Fiet JO, Norton Jr WI and Clouse VGH (2013) Search and discovery by repeatedly successful entrepreneurs. International Small Business Journal 31 (8): 890-913.

Fillis I (2004) The Internationalizing Smaller Craft Firm: Insights from the Marketing/Entrepreneurship Interface. International Small Business Journal 22 (1): 57-82.

Fischer E and Reuber R (2007) The Good, the Bad, and the Unfamiliar: The Challenges of Reputation Formation Facing New Firms. Entrepreneurship Theory and Practice 31 (1): 53-75.

Friedland R (2009) The Endless Fields of Pierre Bourdieu. Organization 16 (6): 887-917.

Fuller T and Tian Y (2006) Social and Symbolic Capital and Responsible Entrepreneurship: An Empirical Investigation of SME Narratives. Journal of Business Ethics 67 (3): 287-304.

Garud R, Schildt HA and Lant TK (2014) Entrepreneurial Storytelling, Future Expectations, and the Paradox of Legitimacy. Organization Science 25 (5): 1479-1492.

Gedajlovic E, Honig B, Moore CB, Payne GT and Wright M (2013) Social Capital and Entrepreneurship: A Schema and Research Agenda. Entrepreneurship Theory and Practice 37 (3): 455-478.

Glynn MA and Lounsbury M (2005) From the Critics' Corner: Logic Blending, Discursive Change and Authenticity in a Cultural Production System. Journal of Management Studies 42 (5): 1031-1055.

Golsorkhi D, Leca B, Lounsbury M and Ramirez C (2009) Analysing, Accounting for and Unmasking Domination: On Our Role as Scholars of Practice, Practitioners of Social Science and Public Intellectuals. Organization 16 (6): 779-797.

Granovetter M (1973) The Strength of Weak Ties. American Journal of Sociology 78 (6): 1360-1380.

Grant P and Perren L (2002) Small Business and Entrepreneurial Research: Meta-theories, Paradigms and Prejudices. International Small Business Journal 20 (2): 185-211.

Gras D and Nason RS (2015) Bric by bric: The role of the family household in sustaining a venture in impoverished Indian slums. Journal of Business Venturing 30 (4): 546-563.

Greene PG and Brown TE (1997) Resource needs and the dynamic capitalism typology. Journal of Business Venturing 12 (3): 161-173.

Greve A and Salaff JW (2003) Social Networks and Entrepreneurship. Entrepreneurship Theory and Practice 28 (1): 1-22.

Grichnik D, Brinckmann J, Singh L and Manigart S (2014) Beyond environmental scarcity: Human and social capital as driving forces of bootstrapping activities. Journal of Business Venturing 29 (2): 310-326.

Harvey C, Maclean M, Gordon J and Shaw E (2011) Andrew Carnegie and the foundations of contemporary entrepreneurial philanthropy. Business History 53 (3): 425-450.

Hycner RH (1985) Some Guidelines for the Phenomenological Analysis of Interview Data. Human Studies 8 (3): 279-303.

Jack SL (2005) The Role, Use and Activation of Strong and Weak Network Ties: A Qualitative Analysis. Journal of Management Studies 42 (6): 1233-1259.

Jack SL, Moult S, Anderson AR and Drakopoulou Dodd S (2010) An entrepreneurial network evolving: Patterns of change. International Small Business Journal 28 (4): 315-337.

Jayawarna D, Jones O and Macpherson A (2014) Entrepreneurial potential: The role of human and cultural capitals. International Small Business Journal 32 (8): 918-943. 
Jayawarna D, Rouse J and Kitching J (2013) Entrepreneur motivations and life course. International Small Business Journal 31 (1): 34-56.

Jennings JE and Brush CG (2013) Research on Women Entrepreneurs: Challenges to (and from) the Broader Entrepreneurship Literature? Academy of Management Annals 7 (1): 663-715.

Jonsson S and Lindbergh J (2013) The Development of Social Capital and Financing of Entrepreneurial Firms: From Financial Bootstrapping to Bank Funding. Entrepreneurship Theory and Practice 37 (4): 661-686.

Karataş-Özkan M (2011) Understanding relational qualities of entrepreneurial learning: Towards a multilayered approach. Entrepreneurship \& Regional Development 23 (9-10): 877-906.

Karataş-Özkan M, Anderson AR, Fayolle A, Howells J and Condor R (2014) Understanding Entrepreneurship: Challenging Dominant Perspectives and Theorizing Entrepreneurship through New Postpositivist Epistemologies. Journal of Small Business Management 52 (4): 589-593.

Karataş-Özkan M and Chell E (2015) Gender Inequalities in Academic Innovation and Enterprise: A Bourdieuian Analysis. British Journal of Management 26 (1): 109-125.

Kim PH, Aldrich H and Keister L (2006) Access (Not) Denied: The Impact of Financial, Human, and Cultural Capital on Entrepreneurial Entry in the United States. Small Business Economics 27 (1): 5-22.

Korsgaard S and Anderson AR (2011) Enacting entrepreneurship as social value creation. International Small Business Journal 29 (2): 135-151.

Kuhn KM and Galloway TL (2015) With a Little Help From My Competitors: Peer Networking Among Artisan Entrepreneurs. Entrepreneurship Theory and Practice 39 (3): 571-600.

Lange D, Lee PM and Dai Y (2011) Organizational Reputation: A Review. Journal of Management 37 (1): 153 184.

Lawrence TB (2004) Rituals and Resistance: Membership Dynamics in Professional Fields. Human Relations 57 (2): 115-143.

Leitch CM, McMullan C and Harrison RT (2013) The Development of Entrepreneurial Leadership: The Role of Human, Social and Institutional Capital. British Journal of Management 24 (3): 347-366.

Lester RH, Hillman AMY, Zardkoohi A and Cannella Jr AA (2008) Former government officials as outside directors: The role of human and social capital. Academy of Management Journal 51 (5): 999-1013.

Lewis KV (2015) Enacting Entrepreneurship and Leadership: A Longitudinal Exploration of Gendered Identity Work. Journal of Small Business Management. Epub ahead of print 28 April 2015. DOI: $10.1111 /$ jsbm. 12175 .

Light I and Dana L-P (2013) Boundaries of Social Capital in Entrepreneurship. Entrepreneurship Theory and Practice 37 (3): 603-624.

Lincoln YS and Guba EG (1985) Naturalistic inquiry. Newbury Park, CA: Sage.

Lounsbury M and Glynn MA (2001) Cultural Entrepreneurship: Stories, Legitimacy, and the Acquisition of Resources. Strategic Management Journal 22 (6/7): 545-564.

Marlow S and McAdam M (2013) Incubation or Induction? Gendered Identity Work in the Context of Technology Business Incubation. Entrepreneurship Theory and Practice. Epub ahead of print 27 August 2013. DOI: 10.1111/etap.12062.

Marvel MR, Davis JL and Sproul CR (2014) Human Capital and Entrepreneurship Research: A Critical Review and Future Directions. Entrepreneurship Theory and Practice. Epub ahead of print 8 October 2014. DOI: 10.1111/etap.12136.

McKeever E, Jack S and Anderson A (2015) Embedded entrepreneurship in the creative re-construction of place. Journal of Business Venturing 30 (1): 50-65.

McLeod C, O'Donohoe S and Townley B (2009) The elephant in the room? Class and creative careers in British advertising agencies. Human Relations 62 (7): 1011-1039.

McLeod C, O'Donohoe S and Townley B (2011) Pot Noodles, Placements and Peer Regard: Creative Career Trajectories and Communities of Practice in the British Advertising Industry. British Journal of Management 22 (1): 114-131.

Miller NJ, Besser T and Malshe A (2007) Strategic Networking among Small Businesses in Small US Communities. International Small Business Journal 25 (6): 631-665.

Nahapiet J and Ghoshal S (1998) Social Capital, Intellectual Capital, and the Organizational Advantage. Academy of Management Review 23 (2): 242-266. 
Özbilgin M and Tatli A (2005) Book Review Essay: Understanding Bourdieu's Contribution to Organization and Management Studies. Academy of Management Review 30 (4): 855-869.

Packalen KA (2007) Complementing Capital: The Role of Status, Demographic Features, and Social Capital in Founding Teams' Abilities to Obtain Resources. Entrepreneurship Theory and Practice 31 (6): 873-891.

Patel PC and Conklin B (2009) The Balancing Act: The Role of Transnational Habitus and Social Networks in Balancing Transnational Entrepreneurial Activities. Entrepreneurship Theory and Practice 33 (5): 10451078.

Patton MQ (2002) Qualitative research and evaluation methods (3rd ed.). Thousand Oaks, CA: Sage.

Ployhart RE, Nyberg AJ, Reilly G and Maltarich MA (2014) Human Capital Is Dead; Long Live Human Capital Resources! Journal of Management 40 (2): 371-398.

Ram M, Theodorakopoulos N and Jones T (2008) Forms of capital, mixed embeddedness and Somali enterprise. Work, Employment \& Society 22 (3): 427-446.

Randle K, Forson C and Calveley M (2014) Towards a Bourdieusian analysis of the social composition of the UK film and television workforce. Work, Employment \& Society. Epub ahead of print 20 October 2014. DOI: $10.1177 / 0950017014542498$.

Reuber AR and Fischer E (2005) The Company You Keep: How Young Firms in Different Competitive Contexts Signal Reputation through Their Customers. Entrepreneurship Theory and Practice 29 (1): 5778.

Reuber AR and Fischer E (2007) Don't rest on your laurels: Reputational change and young technology-based ventures. Journal of Business Venturing 22 (3): 363-387.

Rindova V, Barry D and Ketchen JDJ (2009) Entrepreneuring as emancipation. Academy of Management Review 34 (3): 477-491.

Rindova VP, Williamson IO, Petkova AP and Sever JM (2005) Being Good or Being Known: An Empirical Examination of the Dimensions, Antecedents, and Consequences of Organizational Reputation. Academy of Management Journal 48 (6): 1033-1049.

Rooks G, Klyver K and Sserwanga A (2014) The Context of Social Capital: A Comparison of Rural and Urban Entrepreneurs in Uganda. Entrepreneurship Theory and Practice. Epub ahead of print 21 April 2014. DOI: 10.1111 /etap. 12107.

Sandberg J (2000) Understanding Human Competence at Work: An Interpretative Approach. Academy of Management Journal 43 (1): 9-25.

Sanders P (1982) Phenomenology: A New Way of Viewing Organizational Research. Academy of Management Review 7 (3): 353-360.

Scott M (2012) Cultural entrepreneurs, cultural entrepreneurship: Music producers mobilising and converting Bourdieu's alternative capitals. Poetics 40 (3): 237-255.

Shaw E (2006) Small Firm Networking: An Insight into Contents and Motivating Factors. International Small Business Journal 24 (1): 5-29.

Shaw E, Gordon J, Harvey C and Maclean M (2013) Exploring contemporary entrepreneurial philanthropy. International Small Business Journal 31 (5): 580-599.

Shaw E, Lam W and Carter S (2008) The role of entrepreneurial capital in building service reputation. The Service Industries Journal 28 (7): 899-917.

Shepherd DA (2015) Party On! A call for entrepreneurship research that is more interactive, activity based, cognitively hot, compassionate, and prosocial. Journal of Business Venturing 30 (4): 489-507.

Smith JA (2004) Reflecting on the development of interpretative phenomenological analysis and its contribution to qualitative research in psychology. Qualitative Research in Psychology 1 (1): 39-54.

Smith JA, Flowers P and Larkin M (2009) Interpretative Phenomenological Analysis: Theory Method and Research. London: Sage.

Spivack AJ, McKelvie A and Haynie JM (2014) Habitual entrepreneurs: Possible cases of entrepreneurship addiction? Journal of Business Venturing 29 (3): 651-667.

Stam W, Arzlanian S and Elfring T (2014) Social capital of entrepreneurs and small firm performance: A metaanalysis of contextual and methodological moderators. Journal of Business Venturing 29 (1): 152-173.

Stringfellow L, Shaw E and Maclean M (2014) Apostasy versus legitimacy: Relational dynamics and routes to resource acquisition in entrepreneurial ventures. International Small Business Journal 32 (5): 571-592. 
Sullivan DM and Ford CM (2014) How Entrepreneurs Use Networks to Address Changing Resource Requirements During Early Venture Development. Entrepreneurship Theory and Practice 38 (3): 551574.

Svejenova S (2005) 'The Path with the Heart': Creating the Authentic Career. Journal of Management Studies 42 (5): 947-974.

Tan J, Shao Y and Li W (2013) To be different, or to be the same? An exploratory study of isomorphism in the cluster. Journal of Business Venturing 28 (1): 83-97.

Tatli A, Vassilopoulou J, Özbilgin M, Forson C and Slutskaya N (2014) A Bourdieuan Relational Perspective for Entrepreneurship Research. Journal of Small Business Management 52 (4): 615-632.

Terjesen S and Elam AB (2009) Transnational Entrepreneurs' Venture Internationalization Strategies: A Practice Theory Approach. Entrepreneurship Theory and Practice 33 (5): 1093-1120.

Thompson CJ, Locander WB and Pollio HR (1989) Putting Consumer Experience Back into Consumer Research: The Philosophy and Method of Existential-Phenomenology. Journal of Consumer Research 16 (2): 133-146.

Townley B, Beech N and McKinlay A (2009) Managing in the creative industries: Managing the motley crew. Human Relations 62 (7): 939-962.

Tregear A (2005) Lifestyle, growth, or community involvement? The balance of goals of UK artisan food producers. Entrepreneurship \& Regional Development 17 (1): 1-15.

Überbacher F (2014) Legitimation of New Ventures: A Review and Research Programme. Journal of Management Studies 51 (4): 667-698.

UNDP (2013) Creative Economy Report 2013 Special Edition (report). New York, NY: United Nations Development Programme.

Vershinina N, Barrett R and Meyer M (2011) Forms of capital, intra-ethnic variation and Polish entrepreneurs in Leicester. Work, Employment \& Society 25 (1): 101-117.

Winborg J and Landström H (2001) Financial bootstrapping in small businesses: Examining small business managers' resource acquisition behaviors. Journal of Business Venturing 16 (3): 235-254.

Wry T, Lounsbury M and Glynn MA (2011) Legitimating Nascent Collective Identities: Coordinating Cultural Entrepreneurship. Organization Science 22 (2): 449-463.

Zott C and Huy QN (2007) How Entrepreneurs Use Symbolic Management to Acquire Resources. Administrative Science Quarterly 52 (1): 70-105.

Zou H, Chen X, Lam LWR and Liu X (2015) Psychological capital and conflict management in the entrepreneur-venture capitalist relationship in China: The entrepreneur perspective. International Small Business Journal. Epub ahead of print 5 January 2015. DOI: 10.1177/0266242614563418.

Figure 1. Forms of Capital

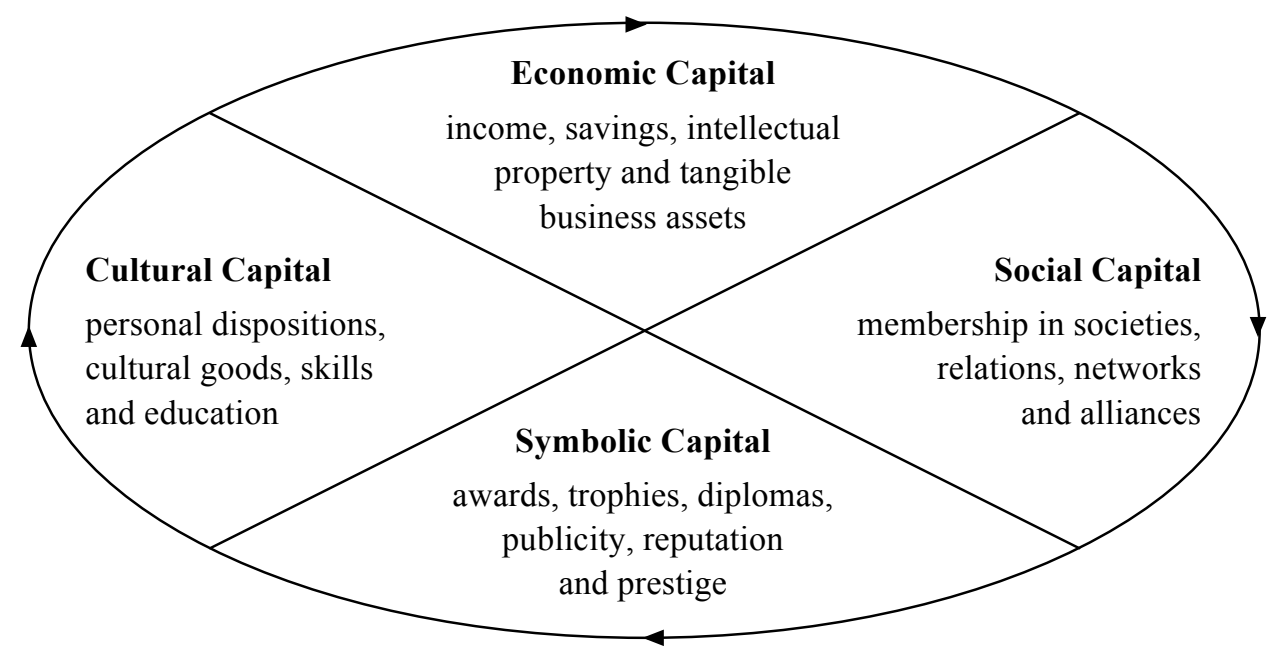




\begin{tabular}{|c|c|c|c|c|c|c|c|c|}
\hline \multicolumn{9}{|c|}{$\begin{array}{l}\text { Table 1. Capital Conversions: Summary of the Literature } \\
(+=\text { facilitator of conversion, }-=\text { inhibitor of conversion })\end{array}$} \\
\hline & & Economic Capital & & Cultural Capital & & Social Capital & & Symbolic Capital \\
\hline \multirow[t]{2}{*}{$\begin{array}{r}\text { Economic } \\
\text { Capital }\end{array}$} & & & + & $\begin{array}{l}\text { Investing in an elite } \\
\text { education facilitates the } \\
\text { development of valuable } \\
\text { skills. } \\
\text { (General, DiMaggio, } \\
\text { 1979) }\end{array}$ & + & $\begin{array}{l}\text { Financing admission to } \\
\text { prestigious schools grants } \\
\text { access to powerful } \\
\text { networks. } \\
\text { (General, Randle et al., } \\
2014)\end{array}$ & + & $\begin{array}{l}\text { Charitable giving can raise } \\
\text { an individual's reputation. } \\
\text { (Entrepreneurs, Harvey et } \\
\text { al., 2011) }\end{array}$ \\
\hline & & & - & $\begin{array}{l}\text { Acquiring new skills or } \\
\text { education is time- } \\
\text { consuming. } \\
\text { (Entrepreneurs, Jayawarna } \\
\text { et al., 2014) }\end{array}$ & - & $\begin{array}{l}\text { Developing stable networks } \\
\text { is a complex process. } \\
\text { (Entrepreneurs, Greve and } \\
\text { Salaff, 2003) }\end{array}$ & - & $\begin{array}{l}\text { Large investments may be } \\
\text { required to maintain a } \\
\text { reputation of philanthropy. } \\
\text { (Entrepreneurs, Shaw et } \\
\text { al., 2013) }\end{array}$ \\
\hline \multirow[t]{2}{*}{$\begin{array}{r}\text { Cultural } \\
\text { Capital }\end{array}$} & + & $\begin{array}{l}\text { Skills enable the production } \\
\text { of cultural products and } \\
\text { artefacts that possess } \\
\text { economic value. } \\
\text { (General, Townley et al., } \\
2009 \text { ) }\end{array}$ & & & + & $\begin{array}{l}\text { High family socioeconomic } \\
\text { status provides access to } \\
\text { wider social networks. } \\
\text { (Entrepreneurs, Anderson } \\
\text { and Miller, 2003) }\end{array}$ & + & $\begin{array}{l}\text { Extant industry experience } \\
\text { can facilitate reputation } \\
\text { building. } \\
\text { (General, Beverland, 2005) }\end{array}$ \\
\hline & - & $\begin{array}{l}\text { Lack of technical expertise } \\
\text { or experience can inhibit } \\
\text { business success. } \\
\text { (Entrepreneurs, } \\
\text { Bhagavatula et al., 2010) }\end{array}$ & & & - & $\begin{array}{l}\text { Standing out from accepted } \\
\text { norms (e.g. through lack of } \\
\text { education) can restrict } \\
\text { access to new networks. } \\
\text { (Entrepreneurs, De Clercq } \\
\text { and Voronov, 2009) }\end{array}$ & - & $\begin{array}{l}\text { Lack of sophistication can } \\
\text { impede status enhancement. } \\
\text { (Entrepreneurs, Lounsbury } \\
\text { and Glynn, 2001) }\end{array}$ \\
\hline \multirow[t]{2}{*}{$\begin{array}{r}\text { Social } \\
\text { Capital }\end{array}$} & + & $\begin{array}{l}\text { Membership in networks } \\
\text { allows access to collectively } \\
\text { held assets, which depends } \\
\text { on the strength of ties. } \\
\text { (Entrepreneurs, Rooks et } \\
\text { al., 2014) }\end{array}$ & + & $\begin{array}{l}\text { The relational process of } \\
\text { entrepreneurial learning } \\
\text { occurs through networks. } \\
\text { (Entrepreneurs, Karataş- } \\
\text { Özkan, 2011) }\end{array}$ & & & + & $\begin{array}{l}\text { Association with reputable } \\
\text { others can create a spill- } \\
\text { over effect. } \\
\text { (Entrepreneurs, Reuber and } \\
\text { Fischer, 2005) }\end{array}$ \\
\hline & - & $\begin{array}{l}\text { Maintaining ties with this } \\
\text { conversion potential is } \\
\text { demanding. } \\
\text { (General, Nahapiet and } \\
\text { Ghoshal, 1998) }\end{array}$ & - & $\begin{array}{l}\text { Accessing contacts to gain } \\
\text { new skills and dispositions } \\
\text { is time-consuming. } \\
\text { (General, Anheier et al., } \\
\text { 1995) }\end{array}$ & & & - & $\begin{array}{l}\text { Being associated with } \\
\text { unreliable partners can } \\
\text { impede reputation-building. } \\
\text { (General, Lange et al., } \\
\text { 2011) }\end{array}$ \\
\hline \multirow[t]{2}{*}{$\begin{array}{r}\text { Symbolic } \\
\text { Capital }\end{array}$} & + & $\begin{array}{l}\text { Displaying symbols of } \\
\text { achievement can establish } \\
\text { legitimacy and increase } \\
\text { sales. } \\
\text { (Entrepreneurs, Zott and } \\
\text { Huy, 2007) }\end{array}$ & + & $\begin{array}{l}\text { Reputation can provide } \\
\text { opportunities for } \\
\text { apprenticeships with } \\
\text { established experts. } \\
\text { (General, Lawrence, 2004) }\end{array}$ & + & $\begin{array}{l}\text { Professional distinction can } \\
\text { facilitate contact and } \\
\text { network building. } \\
\text { (Entrepreneurs, Coulson, } \\
\text { 2012) }\end{array}$ & & \\
\hline & & $\begin{array}{l}\text { A negative reputation based } \\
\text { on past performance can } \\
\text { 'stick' and diminish trust of } \\
\text { investors. } \\
\text { (Entrepreneurs, Fischer } \\
\text { and Reuber, 2007) }\end{array}$ & - & $\begin{array}{l}\text { Lack of symbolic resources } \\
\text { can restrict access to } \\
\text { further education. } \\
(\text { General, McLeod et al., } \\
2009)\end{array}$ & - & $\begin{array}{l}\text { Reputation can be a key } \\
\text { requirement for network } \\
\text { members to bestow } \\
\text { resources. } \\
\text { (Entrepreneurs, } \\
\text { Stringfellow et al., 2014) }\end{array}$ & & \\
\hline
\end{tabular}




\begin{tabular}{|l|l|l|}
\hline \multicolumn{3}{|c|}{ Table 2. Conversions of Economic Capital: Examples from Raw Data } \\
\hline \multicolumn{1}{|c|}{ Cultural Capital } & \multicolumn{1}{|c|}{ Social Capital } & \multicolumn{1}{c|}{ Symbolic Capital } \\
\hline $\begin{array}{l}\text { 'I actually complained about the } \\
\text { course and I got some of my } \\
\text { course fees back. ... I did learn } \\
\text { stuff from it, but ... there wasn't } \\
\text { enough practical stuff.' (Fred) }\end{array}$ & $\begin{array}{l}\text { 'It's not very much [guild } \\
\text { membership]. It's only £22 a } \\
\text { year or something like that.' } \\
\text { (Becky) }\end{array}$ & $\begin{array}{l}\text { 'You pay to get into that one } \\
\text { [magazine] and it's very } \\
\text { important for me to be seen to be } \\
\text { in that.' (Alison) }\end{array}$ \\
\hline - & $\begin{array}{l}\text { 'You have to pay ... an annual } \\
\text { fee for that [membership] ... but } \\
\text { I would say it's worth it.' } \\
\text { (Elaine) }\end{array}$ & $\begin{array}{l}\text { 'If you find the right wholesale } \\
\text { customer it's worth taking a } \\
\text { profit loss, because it boosts your } \\
\text { profile.' (Becky) }\end{array}$ \\
\hline
\end{tabular}

\begin{tabular}{|l|l|l|l|l|}
\hline \multicolumn{3}{|c|}{ Table 3. Conversions of Economic Capital: Comparing the Literature to our Findings } \\
\hline \multicolumn{1}{|c|}{ Cultural Capital } & \multicolumn{1}{|c|}{ Social Capital } & \multicolumn{1}{|c|}{ Symbolic Capital } \\
\hline$+\begin{array}{l}\text { Investing in an elite } \\
\text { education facilitates the } \\
\text { development of valuable } \\
\text { skills. }\end{array}$ & + & $\begin{array}{l}\text { Financing admission to } \\
\text { prestigious schools grants } \\
\text { access to powerful } \\
\text { networks. }\end{array}$ & + & $\begin{array}{l}\text { Charitable giving can raise } \\
\text { an individual's reputation. }\end{array}$ \\
\cline { 2 - 3 } $\begin{array}{l}\text { Some courses are seen as } \\
\text { irrelevant. } \\
\text { College training can provide } \\
\text { some skills and a pool of ties } \\
\text { for continued relational } \\
\text { learning. }\end{array}$ & $\begin{array}{l}\text { Guild membership provides a } \\
\text { variety of relevant strong and } \\
\text { weak ties. } \\
\text { Financial investment in an } \\
\text { elite education is not } \\
\text { considered necessary. }\end{array}$ & $\begin{array}{l}\text { Investments are made to be } \\
\text { featured in key publications. } \\
\text { Price reductions are offered } \\
\text { to attract prestigious } \\
\text { customers. }\end{array}$ \\
\hline$-\begin{array}{l}\text { Acquiring new skills or } \\
\text { education is time- } \\
\text { consuming. }\end{array}$ & $-\begin{array}{l}\text { Developing stable networks is } \\
\text { a complex process. }\end{array}$ & $-\begin{array}{l}\text { Large investments may be } \\
\text { required to maintain a } \\
\text { reputation of philanthropy. }\end{array}$ \\
\hline $\begin{array}{l}\text { There is little or no evidence } \\
\text { of this inhibitor in this study. }\end{array}$ & $\begin{array}{l}\text { There is little or no evidence } \\
\text { of this inhibitor in this study. }\end{array}$ & $\begin{array}{l}\text { There is little or no evidence } \\
\text { of this inhibitor in this study. }\end{array}$ \\
\hline
\end{tabular}

\begin{tabular}{|l|l|l|}
\hline \multicolumn{3}{|c|}{ Table 4. Conversions of Cultural Capital: Examples from Raw Data } \\
\hline \multicolumn{1}{|c|}{ Economic Capital } & \multicolumn{1}{|c|}{ Social Capital } & \multicolumn{1}{c|}{ Symbolic Capital } \\
\hline $\begin{array}{l}\text { 'She wants to get some tips ... } \\
\text { [on] rectangular work ... it's } \\
\text { kind of paid tuition one to one.' } \\
\text { (Craig) }\end{array}$ & $\begin{array}{l}\text { 'Obviously people have asked } \\
\text { me how I've done that [knitting } \\
\text { technique], so I pass it onto other } \\
\text { people.' (Grace) }\end{array}$ & $\begin{array}{l}\text { 'It [product] was in all the ... } \\
\text { magazines and so there was more } \\
\text { kudos to it.' (Denise) }\end{array}$ \\
\hline $\begin{array}{l}\text { 'When you've made the things } \\
\text { that you sell, you know how } \\
\text { much work goes into ... that } \\
\text { pretty good price.' (Hannah) }\end{array}$ & $\begin{array}{l}\text { 'It was good to meet people } \\
\text { through that [studying] - good to } \\
\text { network.' (Jessica) }\end{array}$ & $\begin{array}{l}\text { 'I don't want them [collectors] to } \\
\text { get bored of the same styles, so } \\
\text { I'm always trying to develop a } \\
\text { different range.' (Elaine) }\end{array}$ \\
\hline
\end{tabular}

\begin{tabular}{|c|l|c|c|c|c|}
\hline \multicolumn{6}{|c|}{ Table 5. Conversions of Cultural Capital: Comparing the Literature to our Findings } \\
\hline \multicolumn{1}{|c|}{ Economic Capital } & & \multicolumn{1}{|c|}{ Social Capital } & \multicolumn{1}{c|}{ Symbolic Capital } \\
\hline$+\begin{array}{l}\text { Skills enable the production } \\
\text { of cultural products and } \\
\text { artefacts that possess } \\
\text { economic value. }\end{array}$ & + & $\begin{array}{l}\text { High family socioeconomic } \\
\text { status provides access to } \\
\text { wider social networks. }\end{array}$ & $+\begin{array}{l}\text { Extant industry experience } \\
\text { can facilitate reputation } \\
\text { building. }\end{array}$ \\
\hline
\end{tabular}




\begin{tabular}{|l|l|l|l|l|}
\hline $\begin{array}{l}\text { Skills and expertise form the } \\
\text { basis of these craft ventures. } \\
\text { Technical experience enables } \\
\text { the paid tuition of others. }\end{array}$ & $\begin{array}{l}\text { Cultural capital is shared } \\
\text { within social networks. } \\
\text { Attending college/university } \\
\text { helps build vital networks. }\end{array}$ & $\begin{array}{l}\text { Individual style is used to } \\
\text { develop a reputation and is } \\
\text { derived from personal } \\
\text { cultural capital. }\end{array}$ \\
\hline$-\begin{array}{l}\text { Lack of technical expertise } \\
\text { or experience can inhibit } \\
\text { business success. }\end{array}$ & - & $\begin{array}{l}\text { Standing out from accepted } \\
\text { norms (e.g. through lack of } \\
\text { education) can restrict } \\
\text { access to new networks. }\end{array}$ & $-\begin{array}{l}\text { Lack of sophistication can } \\
\text { impede status enhancement. }\end{array}$ \\
\cline { 2 - 3 } $\begin{array}{l}\text { Social capital is used to } \\
\text { substitute for a lack of } \\
\text { specific skills. }\end{array}$ & $\begin{array}{l}\text { There is little or no evidence } \\
\text { of this inhibitor in this study. }\end{array}$ & $\begin{array}{l}\text { There is little or no evidence } \\
\text { of this inhibitor in this study. }\end{array}$ \\
\hline
\end{tabular}

\begin{tabular}{|l|l|l|}
\hline \multicolumn{3}{|c|}{ Table 6. Conversions of Social Capital: Examples from Raw Data } \\
\hline \multicolumn{1}{|c|}{ Economic Capital } & \multicolumn{1}{|c|}{ Cultural Capital } & \multicolumn{1}{c|}{ Symbolic Capital } \\
\hline $\begin{array}{l}\text { 'My brother has helped me out } \\
\text {.. with money for that } \\
\text { [acquiring machinery].' (Fred) }\end{array}$ & $\begin{array}{l}\text { 'A friend of ours ... is just in } \\
\text { university doing media studies } \\
\text {.. he's gonna do a cool video for } \\
\text { us and that might get us started } \\
\text {.. on YouTube.' (Craig) }\end{array}$ & $\begin{array}{l}\text { 'If I want anything in the } \\
\text { magazines .. I phone them } \\
\text { [publishers] up and say 'Can I } \\
\text { have this in please" and they } \\
\text { usually do it.' (Alison) }\end{array}$ \\
\hline $\begin{array}{l}\text { 'You tend to find after a show } \\
\text { your sales tend to go up.' (Iona) }\end{array}$ & $\begin{array}{l}\text { 'We had a residential weekend } \\
\text { and ... it wasn't just learning ... } \\
\text { somebody else's technique; it } \\
\text { was as much about how to } \\
\text { generate ideas.' (Grace) }\end{array}$ & $\begin{array}{l}\text { 'When I was first starting out ... } \\
\text { it helped to raise my profile quite } \\
\text { a bit that I was associated with } \\
\text { someone [peer] who was already } \\
\text { thought of so highly.' (Becky) }\end{array}$ \\
\hline
\end{tabular}

\begin{tabular}{|c|c|c|c|c|c|}
\hline & Economic Capital & & Cultural Capital & & Symbolic Capital \\
\hline \multirow[t]{2}{*}{+} & $\begin{array}{l}\text { Membership in networks } \\
\text { allows access to collectively } \\
\text { held assets, which depends } \\
\text { on the strength of ties. }\end{array}$ & \multirow[t]{2}{*}{+} & $\begin{array}{l}\text { The relational process of } \\
\text { entrepreneurial learning } \\
\text { occurs through networks. }\end{array}$ & \multirow[t]{2}{*}{+} & $\begin{array}{l}\text { Association with reputable } \\
\text { others can create a spill-over } \\
\text { effect. }\end{array}$ \\
\hline & $\begin{array}{l}\text { Contacts provide resources } \\
\text { for free or at lower cost. } \\
\text { Sales are generated through } \\
\text { both strong and weak ties. } \\
\text { Social and cultural capital } \\
\text { combine to provide a focus } \\
\text { for referrals from competitors. }\end{array}$ & & $\begin{array}{l}\text { Novel techniques and cultural } \\
\text { products are co-created. } \\
\text { Skills are acquired from peers } \\
\text { suppliers, family and friends. } \\
\text { Social capital is used to } \\
\text { substitute others' cultural } \\
\text { capital for one's own. }\end{array}$ & & $\begin{array}{l}\text { Ties with well-placed others } \\
\text { facilitate reputation-building, } \\
\text { access to prestigious events } \\
\text { and media exposure. } \\
\text { Large numbers of followers } \\
\text { help increase success in } \\
\text { public choice awards. }\end{array}$ \\
\hline \multirow[t]{2}{*}{-} & $\begin{array}{l}\text { Maintaining ties with this } \\
\text { conversion potential is } \\
\text { demanding. }\end{array}$ & & $\begin{array}{l}\text { Accessing contacts to gain } \\
\text { new skills and dispositions is } \\
\text { time-consuming. }\end{array}$ & \multirow[t]{2}{*}{-} & $\begin{array}{l}\text { Being associated with } \\
\text { unreliable partners can } \\
\text { impede reputation building. }\end{array}$ \\
\hline & $\begin{array}{l}\text { There is little or no evidence } \\
\text { of this inhibitor in this study. }\end{array}$ & & $\begin{array}{l}\text { Relational forms of knowledge } \\
\text { creation and sharing appear } \\
\text { easy and natural. }\end{array}$ & & $\begin{array}{l}\text { There is little or no evidence } \\
\text { of this inhibitor in this study. }\end{array}$ \\
\hline
\end{tabular}




\begin{tabular}{|l|l|l|}
\hline \multicolumn{3}{|c|}{ Table 8. Conversions of Symbolic Capital: Examples from Raw Data } \\
\hline \multicolumn{1}{|c|}{ Economic Capital } & \multicolumn{1}{|c|}{ Cultural Capital } & \multicolumn{1}{c|}{ Social Capital } \\
\hline $\begin{array}{l}\text { 'I managed to build up a good } \\
\text { enough name that even though } \\
\text { there are more people doing it } \\
\text { now, people are still buying from } \\
\text { me.' (Becky) }\end{array}$ & $\begin{array}{l}\text { 'All these projects ... brought me } \\
\text { into their attention ... I was very } \\
\text { fortunate to spend a couple of } \\
\text { days with him [expert] ... giving } \\
\text { me a bit of tutoring.' (Elaine) }\end{array}$ & $\begin{array}{l}\text { 'Last year they did a profile on } \\
\text { me in the American magazine ... } \\
\text { which was fantastic, which gets } \\
\text { you more attention, which gives } \\
\text { you more customers.' (Alison) }\end{array}$ \\
\hline $\begin{array}{l}\text { 'Reputation is ... everything, cos } \\
\text { it would only take one negative } \\
\text { [online] review ... they're not } \\
\text { gonna take the risk of having } \\
\text { somebody that's not gonna } \\
\text { produce a good craft.' (Hannah) }\end{array}$ & $\begin{array}{l}\text { 'The reason for going into this } \\
\text { competition was ... a travel } \\
\text { bursary, so ... I got into the } \\
\text { studios in Milan and ... that was } \\
\text { very useful experience.' (Iona) }\end{array}$ & $\begin{array}{l}\text { 'It [reputation] is massive, it is } \\
\text { really huge and you do really } \\
\text { have to go above and beyond in } \\
\text { customer service.' (Jessica) }\end{array}$ \\
\hline
\end{tabular}

\begin{tabular}{|c|c|c|c|c|c|}
\hline & Economic Capital & & Cultural Capital & & Social Capital \\
\hline \multirow[t]{2}{*}{+} & $\begin{array}{l}\text { Displaying symbols of } \\
\text { achievement can establish } \\
\text { legitimacy and increase } \\
\text { sales. }\end{array}$ & \multirow[t]{2}{*}{+} & $\begin{array}{l}\text { Reputation can provide } \\
\text { opportunities for } \\
\text { apprenticeships with } \\
\text { established experts. }\end{array}$ & \multirow[t]{2}{*}{+} & $\begin{array}{l}\text { Professional distinction can } \\
\text { facilitate contact and } \\
\text { network building. }\end{array}$ \\
\hline & $\begin{array}{l}\text { Reputation, a strong online } \\
\text { status and winning } \\
\text { competitions all convert into } \\
\text { sales. }\end{array}$ & & $\begin{array}{l}\text { Competition success and } \\
\text { international reputation } \\
\text { facilitate learning from high- } \\
\text { status others. }\end{array}$ & & $\begin{array}{l}\text { Reputation and media } \\
\text { exposure generate a following } \\
\text { and increase the size of } \\
\text { networks. }\end{array}$ \\
\hline \multirow[t]{2}{*}{-} & $\begin{array}{l}\text { A negative reputation based } \\
\text { on past performance can } \\
\text { 'stick' and diminish trust of } \\
\text { investors. }\end{array}$ & \multirow[t]{2}{*}{ - } & $\begin{array}{l}\text { Lack of symbolic resources } \\
\text { can restrict access to } \\
\text { further education. }\end{array}$ & \multirow[t]{2}{*}{ - } & $\begin{array}{l}\text { Reputation can be a key } \\
\text { requirement for network } \\
\text { members to bestow } \\
\text { resources. }\end{array}$ \\
\hline & $\begin{array}{l}\text { Negative and even neutral } \\
\text { online feedback can be } \\
\text { harmful to the business. }\end{array}$ & & $\begin{array}{l}\text { There is little or no evidence } \\
\text { of this inhibitor in this study. }\end{array}$ & & $\begin{array}{l}\text { There is little or no evidence } \\
\text { of this inhibitor in this study. }\end{array}$ \\
\hline
\end{tabular}

\begin{tabular}{|c|c|c|}
\hline \multicolumn{3}{|l|}{ Appendix. Data Coding } \\
\hline Examples from Raw Data & $\begin{array}{l}\text { 1st Order } \\
\text { Concepts }\end{array}$ & $\begin{array}{l}\text { 2nd Order } \\
\text { Themes }\end{array}$ \\
\hline \multicolumn{3}{|l|}{ Economic Capital } \\
\hline $\begin{array}{l}\text { 'There are big highs and lows ... some months you could make thousands } \\
\text { of pounds and other months you'd make not so much.' (Denise) }\end{array}$ & income & \multirow{2}{*}{ financial assets } \\
\hline $\begin{array}{l}\text { 'I've always been careful with my money, because ... if I had the } \\
\text { money, then I knew I could do my own thing.' (Jessica) }\end{array}$ & savings & \\
\hline $\begin{array}{l}\text { 'Anything written, you have copyright over. But once you do a pattern } \\
\text { it's much more difficult ... even if you actually register it.' (Grace) }\end{array}$ & designs & intangible assets \\
\hline 'You can't make stuff ... unless you've got enough equipment.' (Fred) & equipment & \multirow{4}{*}{ tangible assets } \\
\hline 'From when I was a student ... silver has quadrupled in price.' (Elaine) & materials & \\
\hline $\begin{array}{l}\text { 'At least we're not paying that rent anymore. We bought it [the studio] } \\
\text { outright, so ... in terms of cash-flow, it's spectacular.' (Craig) }\end{array}$ & property & \\
\hline $\begin{array}{l}\text { 'I can't go into creating product ranges and ordering stuff if I can't sell } \\
\text { it, cos the last thing I want is ... a load of stock that I can't shift.' (Iona) }\end{array}$ & stock & \\
\hline
\end{tabular}




\begin{tabular}{|c|c|c|}
\hline \multicolumn{3}{|l|}{ Cultural Capital } \\
\hline $\begin{array}{l}\text { 'I don't pretend to be all-knowing, but when you've got a few years } \\
\text { under your belt ... I think it's valuable to share it with people.' (Grace) }\end{array}$ & experience & \multirow{3}{*}{$\begin{array}{l}\text { embodied } \\
\text { cultural capital }\end{array}$} \\
\hline $\begin{array}{l}\text { 'If you collect bears, your group of bears is called a hug, it's a hug of } \\
\text { bears - see, all this knowledge ... [I] learnt.' (Alison) }\end{array}$ & knowledge & \\
\hline $\begin{array}{l}\text { 'It helps that I can draw ... cos some people come in .... and they've got } \\
\text { a specific thing in their head and we design it together.' (Denise) }\end{array}$ & skills & \\
\hline $\begin{array}{l}\text { 'I studied English literature at university ... even if you can't find } \\
\text { immediate use for it, just learning things is useful in itself.' (Becky) }\end{array}$ & education & \multirow{2}{*}{$\begin{array}{l}\text { institutionalised } \\
\text { cultural capital }\end{array}$} \\
\hline 'I went to, like, a workshop ... and had a go at binding books.' (Hannah) & training & \\
\hline $\begin{array}{l}\text { 'It's very personal, as well, a piece of pottery ... you know, it's sort of } \\
\text { personal taste and experience and all sorts of things come into it.' (Fred) }\end{array}$ & craft items & \multirow{2}{*}{$\begin{array}{l}\text { objectified } \\
\text { cultural capital }\end{array}$} \\
\hline $\begin{array}{l}\text { 'People want } \ldots \text { to do things that are unusual } \ldots \text { they are not particularly } \\
\text { keen on doing commercial kits that everybody else can get.' (Grace) }\end{array}$ & craft kits & \\
\hline \multicolumn{3}{|l|}{ Social Capital } \\
\hline $\begin{array}{l}\text { 'There may well be a fellow who's worked all their life in that field and } \\
\text { could give insights.' (Iona) }\end{array}$ & guilds & \multirow{2}{*}{$\begin{array}{l}\text { business } \\
\text { networks }\end{array}$} \\
\hline $\begin{array}{l}\text { 'If there is anything you want in the newsletter, you get in touch with } \\
\text { them [the business incubator].' (Hannah) }\end{array}$ & $\begin{array}{l}\text { support } \\
\text { groups }\end{array}$ & \\
\hline ‘My boyfriend was a massive, massive help!’ (Jessica) & family & \multirow[b]{2}{*}{ confidantes } \\
\hline $\begin{array}{l}\text { 'I have a friend, who is a hotel inspector, who is trying to get them } \\
\text { [products] into different hotels and places, which is quite fun.' (Denise) }\end{array}$ & friends & \\
\hline $\begin{array}{l}\text { 'I have some of the nicest collectors, ... I call them my lovely collectors, } \\
\text { Adam calls them my stalkers - somewhere in between I think.' (Alison) }\end{array}$ & collectors & \multirow{3}{*}{ followers } \\
\hline $\begin{array}{l}\text { ‘Some people don't even look at websites, they just ... [use] Facebook, } \\
\text { you know, "does anybody know somebody who can do baskets?”' (Craig) }\end{array}$ & $\begin{array}{l}\text { online } \\
\text { followers }\end{array}$ & \\
\hline $\begin{array}{l}\text { 'I get wholesale requests all the time ... people that have bought stuff } \\
\text { from me for personal use may also own a yarn shop.' (Becky) }\end{array}$ & wholesalers & \\
\hline $\begin{array}{l}\text { 'It's good to have a little network of a few people and you can ask } \\
\text { people things, cos it's quite technical.' (Fred) }\end{array}$ & makers & \multirow{2}{*}{ peers } \\
\hline $\begin{array}{l}\text { 'If I'm having a problem with something technically, I know I could } \\
\text { phone up my old tutor to ask him [for] advice.' (Elaine) }\end{array}$ & teachers & \\
\hline 'I'm gonna get some interns as well ... who will help me.' (Jessica) & apprentices & \multirow[b]{2}{*}{ pupils } \\
\hline $\begin{array}{l}\text { 'I go back to the same sort of people ... lots of people want to know } \\
\text { what's next. I have a database of people for workshops.' (Grace) }\end{array}$ & students & \\
\hline $\begin{array}{l}\text { 'If you can, talk to them [suppliers] ... they can unwittingly give you } \\
\text { help and ideas for all sorts of things, even new stuff.' (Iona) }\end{array}$ & \begin{tabular}{|l|} 
material \\
suppliers
\end{tabular} & \multirow{2}{*}{ suppliers } \\
\hline $\begin{array}{l}\text { 'My web hosting [is] provided by the same people and it's a small } \\
\text { independent company as well, which is really, really helpful.' (Becky) }\end{array}$ & $\begin{array}{l}\text { website } \\
\text { developers }\end{array}$ & \\
\hline \multicolumn{3}{|l|}{ Symbolic Capital } \\
\hline 'So the accolade, I've got the certificates up there on the wall.' (Elaine) & certificates & \multirow{2}{*}{ awards } \\
\hline 'That's my award cabinet ... [I'm] very pleased with the top shelf!' (Alison) & trophies & \\
\hline 'That's a really decent place to have my stuff.' (Fred) & gallery pieces & \multirow{3}{*}{ exhibitions } \\
\hline $\begin{array}{l}\text { 'You can see a piece in the Kelvingrove Art Museum, } \ldots \text { one in the } \\
\text { National Museum of Scotland, you can see one in the V\&A.' (Elaine) }\end{array}$ & $\begin{array}{l}\text { museum } \\
\text { displays }\end{array}$ & \\
\hline 'I'm doing another, a trunk show ... in this kind of small world ... & shows & \\
\hline $\begin{array}{l}\text { 'I've done articles for magazines, } \ldots \text { which has publicised the book - it's } \\
\text { also obviously got my name out there.' (Grace) }\end{array}$ & $\begin{array}{l}\text { magazine } \\
\text { articles }\end{array}$ & \multirow{2}{*}{ media coverage } \\
\hline $\begin{array}{l}\text { 'She is quite a prominent knitwear designer, she blogged about how } \\
\text { fabulous the studio was and I got an order off the back of that.' (Denise) }\end{array}$ & $\begin{array}{l}\text { online } \\
\text { features }\end{array}$ & \\
\hline $\begin{array}{l}\text { 'She said she could always recognise the baskets when they came in, } \\
\text { because they were so much neater and more beautiful.' (Craig) }\end{array}$ & esteem & \multirow{2}{*}{ reputation } \\
\hline $\begin{array}{l}\text { 'It would only take one negative review ... you need to make sure y } \\
\text { are customer orientated the whole time.' (Hannah) }\end{array}$ & reviews & \\
\hline
\end{tabular}

